\title{
The Migrations and the Mass Media; Conceptualization of the Freedom from Fear and Want Paradigm
}

\author{
Faruk HADŽIĆ ${ }^{l}$
}

\begin{abstract}
The paper explores migrations and media concerning the human security conceptualization dilemma. Prevention programs of media propaganda as a separate phenomenon based on proper longitudinal, multidisciplinary research into the etiology and consequences can contribute to human rights. Migration is an essential factor of human and international security, and the lack of adequate normative dynamics neglects human rights accelerating new conflicts. The term migrant, and such homogenization in which a group of people tries to portray themselves as a mass in which all have the same characteristics, goals are fertile ground for expanding hate speech, incitement, and various forms of generalization. Migrants are not recognized as relevant and valuable sections of the assembly with particular needs. Viewing members of other cultures as "enemies" or "others" that can harm collective identity is not a liberal principle but a nationalist one and a significant portion of anti-migrant attitudes are interpreted from a cultural perspective. Discrimination and economic inequality jeopardize the human security paradigm impacting psychological well-being within moderators' influence and in mind attending actual conflicts. The fight against hate speech must be reactive (sanctioning) and proactive media education and literacy programs aimed at the general population. Minimizing sensationalism journalism undermines the quality of public debate and thus, in a way, legitimizes its low level of communication culture in the public space from which it develops, and inappropriate speech flourishes uncontrollably. By accepting liberal principles, states should promote equality and respect for society's identity.
\end{abstract}

Keywords: Mass media, Propaganda, Migrations, Human rights, Human security, Freedom from fear, Freedom from want

\footnotetext{
${ }^{1}$ Independent researcher, Bosnia and Herzegovina, faruk.hadzic01@gmail.com https://orcid.org/0000-0003-1158-7858

Research Article - Submit Date: 17.12.2020, Acceptance Date: 24.04.2021

DOI: 10.17932/IAU.IJMCL.2015.014/ijmcl_v07i1005
} 
The Migrations and the Mass Media; Conceptualization of the Freedom from Fear and Want Paradigm

\section{ÖZ}

Bu çalışma insan güvenliğinin kavramsallaşmasına ilişkin olarak göç ve medyayı incelemektedir. Etiyoloji ve sonuçları üzerine uzunlamasına ve çok disiplinli araştırmalara dayanan ayrı bir fenomen olarak medya propagandalarını önleme programları insan haklarına katkıda bulunabilir. Göç, insan güvenliği ve uluslararası güvenlik için önemli bir etkendir. Yeterli normatif dinamiklerin eksikliği, insan haklarının yeni zıtlıklar yaratmasını göz ardı etmektedir. Göçmen terimi ve kendilerini aynı özelliklere, amaçlara sahip bir kitle olarak göstermeye çalışan bir grup insanın oluşturduğu bu homojenizasyon nefret söyleminin, tahrikin ve türlü genelleştirme biçimlerinin türemesi için verimli bir alandır. Göçmenler toplumun belirli ihtiyaçlara sahip, toplumla bağlantılı ve toplumun değerli bir kesimi olarak görülmemektedir. Diğer kültürlerin bireylerini kolektif kimliğe zarar verebilecek "düşman" ya da "öteki” olarak görmek liberal değil milliyetçi bir ilkedir ve göçmen karşıtı tutumların önemli bir çoğunluğu kültürel bir bakış açısından ortaya çıkmaktadır. Ayrımcılık ve ekonomik eşitsizlik, moderatörlerin etkisi dâhilinde ve gerçek çatışmalara katılma konusunda psikolojik refahı etkileyen insan güvenliği paradigmasını tehlikeye atmaktadır. Nefret söylemine karşı verilen mücadele, nüfusun geneline yönelik reaktif (yaptırımlı) ve proaktif medya eğitimi, okuryazarlık programlarıyla yapılmalıdır. Gazetecilikte sansasyonalizmi asgari düzeye indirmek toplumsal tartı̧̧manın kalitesini düşürür ve böylece içinde geliştiği kamusal alandaki düşük iletişim kültürünü meşrulaştırır, uygunsuz söylemler kontrol edilemez bir şekilde artar. Devletler liberal ilkeleri kabul ederek toplumun kimliğine yönelik eşitliği ve saygıyı teşvik etmelidir.

Anahtar Kelimeler: Kitle Illetişim, Propaganda, Göç, Insan Hakları, İnsan Güvenliği, Korkudan Kurtulma, Yoksunluktan Kurtulma

\section{INTRODUCTION}

Globalization theorists believe that migrations are just a logical sequence of globalization events and that demographic imbalance and inequalities in life chances are their primary cause. (Cocker, 2006) The 21st century will be a "century of migration," and, in support of that, I emphasize the fact that it is at its beginning there were more migrants than ever before in history, unlike the 20th century, which is larger was partly characterized by refugees as carriers of migration processes.

The media as facilitators of public debate are an essential tool for managing society's enlarging diversity. However, when reporting on refugees and migrants' arrival in Europe during 2015-2016, the media played a central role in shaping these issues as crisis events. This kind of perspective contributed to the public's 
negative and sometimes hostile attitudes towards newcomers. Several Council of Europe confirmed it reports an examination of the media's role, the expectations and needs in the communication domain of migrants and refugees themselves, and the community's media responses. Both reports contain recommendations for an inclusive media policy towards migrants and refugees. The studies highlighted the demand for shared action at all levels; policymakers, civil society organizations, public services, commercial and community media.

Simultaneously, the refugee crisis has stimulated radical nationalism, political narratives, xenophobic intolerance towards immigrants globally. Therefore, we can say that the refugee crisis has spurred the rise of populism, that is, that migration is a crucial factor responsible for the growing popularity of the rightwing political option. It can be concluded, based on scientific articles and publications, daily newspapers, websites, and blogs deal with this topic, which was published in 2015-2020, that the notable media role is in the rise of rightwing populism discourses. Although some authors point out that media are the main culprits for this rise, this cannot be argued with certainty because there are not enough empirical analyzes about this connection. Therefore, it would be more appropriate to call media principal "accomplices," co-responsible for empowering populism and prejudice. Thus, the dominant tone in the media indicates a suspicious attitude towards migrants' rationality.

The negative dynamics of the relationship between groups in conflict, except which has implications for functioning at the state union level, leads to psychological consequences on an individual level. In particular, perception of intergroup threat, which is perceived as real, economic threat, a threat of a political nature, where the entry of representatives external groups in the legislative and political structures of the state is perceived as a danger to the survival of one's group, or a symbolic threat, at individuals who feel it leads to negative psychological consequences welfare. The issue of the immigrant is also the sociological problem of the "foreigner." A foreigner is not just a psycho-social category but an ontological category - what makes a man a foreigner? Being a foreigner is a social status that combines the affiliation and non-affiliation of a foreigner. The stranger embodies in himself the unity of detachment (eviction from a particular space) and fixation (attachment to a new spatial framework). However, this unity or synthesis creates new constellations - the distance within the stranger's relationship means that "proximity" is far, and "distance" is close. The stranger always maintains a certain distance from the new spatial framework and people. This internal and external distance cannot be removed entirely.

Given that most of the immigrant population is of the Islamic faith, there are views that Muslim culture conflicts with the West on issues such as freedom of expression, women's rights, and the separation of state and church. Europeans 
expect a strict separation of the secular from the religious, and some Muslims find it difficult to comprehend the difference between the secular and the religious (the Qur'an prescribes everything). Europeans demand freedom of expression and tolerance of diversity (and therefore openly criticize religions), and Islam often strongly condemns any encroachment on its truths. There are differences regarding women's rights, but (studying the Qur'an), we can conclude that the position of women in Arab countries is primarily the result of long-inherited customs rather than the regulations of the Qur'an.

If there is more news about terrorist, physical, and sexual attacks by Muslims during the immigration wave in Europe, the public creates a negative image of immigrants. Terrorism usually gets ample media coverage by presenting terrorist violence through horrific images on T.V. and photographs in the press, such as images of corpses, funerals, bereaved relatives, and the destruction of buildings. Globalization and media development have influenced the development of terrorism. Thus Islam is often left with a place in the black chronicles. Migration in the most liberal democracies experienced the cultural threat, with the intensity and content of attitudes depending on the national context and several contextual factors. The rhetoric of political actors and media reports marked with Islamophobic tones dramatically influences citizens' perception of Islam as a unified and militant religion.

In the era of fundamental values, the very notions of trans-nationality and postnationality are called into question. Such a trend should not hide that the nationstate model has undergone remarkable changes in the era of globalization, becoming less sustainable and less critical for multiculturalism processes. Social identity theory states that greater identification with one's nation is associated with a more significant positive bias towards one's own and a negative one towards an outside group (Tajfel \& Turner, 2004). Thus, preserving a positive national identity. As an ideology, multiculturalism seeks to strike a balance between unity and diversity in society. This ideology implies the promotion of cultural diversity and insists on equality and respect for all cultural groups. Therefore, it is accepted as a political solution in many Western countries, but empirical research shows that it is more accepted at the political than at the civilian level (Citrin et al., 2001).

Media "hate behind the curtain," through the concept of "mass psychology," regardless of the category of migrants, contributes to dehumanization, loss of identity, even gender orientation through the frame of collective illegal border crossing. (Hadžić, 2020, p. 24) The loud public within mass psychology discourse often reflects the power structures and aided by the detection, external and internal enemies. The migrant crisis triggered xenophobia and the dispersion of anti-immigrant sentiments that became a reference matrix for radical politics. 
Anti-immigrant discourse appears in parallel as a form of language use and a form of social and political interaction and the threat of terrorism, which is regularly associated with Islam. The antagonistic stereotypical narrative about migrants starts from the thesis that they constitute a retrograde social group representing an economic and security threat to the domicile population. It is not capable of cultural assimilation in the countries of transit, reception, and final destination.

A new security paradigm in the 21 st century deepens from the state to non-state reference facilities. It is how concepts like economic, societal, ecological, political, human, collectives, and global security, putting the individual at the center of events. As a people-centered approach, the human security concept has gained considerable attention recently. The author favors a broad definition; the human security concept provides the means to assess the root causes of conflict, propose adequate crisis management policies, and provide the means to build sustainable peace. (Taylor, 2004) Moreover, human security concept focuses on social and economic issues as they affect the individual, arguing that security depends on the broader and diverse framework of factors that require a comprehensive approach effectively. The Social Report, the UN Development Program (UNDP) in 1994 expanded the conceptualization of security and rehabilitated two fundamental freedoms of the 1945 UN Charter: "freedom from want" and "freedom from fear." Moreover, we can single out seven related human security elements: economic security, food security, health security, environmental security, personal security, social security, and political security. The democracy, in its arrival, as a promise in the Universal Declaration of Human Rights, implies everyone, without restrictions. Everyone who is not the same and not related, but on the contrary, is singular in his human form. This promise is deeply connected with the belief in a different social and international order that will enable the world to be equally developed, be ruled by peace and the absence of poverty, and that everyone has the right to such an order to have the right to rights. It is up to us to ask ourselves seventy two years later why this promise seems not only unbelievable but almost ironic today. In the spirit of that, even earlier recognized right of the individual to "freedom from fear," the author maintains that the media propaganda as a separate phenomenon, deserves to be scientifically researched and recognized.

\section{AIMS AND METHOD}

The paper explores migrations and mass media propaganda concerning human security conceptualization dilemma. The multidisciplinary approach to canalysis aims to understand how migrations and mass media are being addressed as essential for the human security paradigm. The literature review highlights knowledge and research gaps and identifies relevant initiatives. The study 
The Migrations and the Mass Media; Conceptualization of the Freedom from Fear and Want Paradigm

problematizes insights into the importance of global awareness and refinement of normative solutions.

\section{MIGRATIONS}

Demographic imbalance, wars, and social vulnerability of individual peoples in a world of contradictions between the poor and the rich will continue to result in waves the migration of one people to another. Today's disturbing social and racial reactions may be minor compared to what will happen in the forthcoming future. These migrations are large-scale, they cause social and security shocks, so they are often referred to as "migration of peoples." Migrations are most often caused by wars and then unbearable and inhumane living conditions. Explosive population growth, with declining resources in underdeveloped countries and countries in development, wars, and the widening gap between rich and poor, in addition to the danger from internal migrations and various conflicts, led to mass migrations to other countries and regions. Such an objective state is from individual center power in the West and is instrumentalized by managing migrant flows and waves.

In a short time, from a vain discourse on the need for solidarity, we have societies in which various forms of discrimination are openly accepted, all to preserve "our" identity. An atmosphere of hatred towards foreigners was created. Thus, protests with messages have been held in Poland for years, with messages such as: "Islamic hordes rape, beat, kill. Do not let that happen to you either. Poland must remain Catholic." (Al Jazeera, 2018) In the US, this policy began to be vigorously pursued after Donald Trump took office. Thus, statements, such as that of prominent American right-winger R. Spencer, about how Latin Americans threaten US national identity have become common. The rise of militant and radical right-wing groups in the US is an undoubted fact. (Beirich \& Buchanan, 2018) Accordingly, new organizations have emerged, such as the Patriot Front, the Fraternal Order of Alt Knights, which have created new leaders like Mike Enoch or Richard Spencer, who screamed, "Hail Trump!" While European rightwingers' anger is directed at Syrians, Iraqis, Libyans, and everyone else, in the United States, the right has directed its anger at Latin Americans, who, in line with Eurocentric policies, are almost entirely ignored in the local and European media.

Perception of an intergroup threat as a stressor and effect on psychological wellbeing was a topic explored by groups of researchers in the once very politically unstable and still vulnerable region of Northern Ireland, on the group respondents of the Protestant and Catholic faiths history. It was found that perceived discrimination by an outside group or political experience conflict as a variant of 
threat from an outside group leads to reduced psychological well-being in respondents due to increased stress. Simultaneously, this does not necessarily mean real perceived threat, rather than just the threat's perception, which indicates the power of psychological perception of conflict. The presence of stressors related to intergroup threat and witnessing intergroup conflicts led to more robust social identifications with their group, which are the authors interpreted as a mechanism of coping with psychological distress, and what in context socially psychological interpretation of prejudice, code minority, and majority groups can lead to isolation from the external group and even greater tensions in a particular social context. (Schmid \& Muldoon, 2015)

According to the Integrated treat theory, an intergroup threat is experienced when members of one group perceive that another group is in a position to cause them some form of harm. (Stephan \& Stephan, 2000) Constructing immigrants as a group, whether they are migrants, refugees, or asylum seekers, tends to encourage the perception that "their "interests, values, and traditions are competing with "ours." It is an ambitious vision stimulating negative emotions, such as fear, and negative attitudes, in the form of prejudice. (Hadžić, 2020) Social identity and the internalization of group values and the external group's perception as a threat, and in the political aspect, the acceptance of more conservative political ideologies that propagate the protection of these same group values, are the primary sociopsychological mechanisms of prejudice. The literature dealing with migration provides an unlimited source of information; however, any research on a phenomenon within the concept of migration is an individual story.

Ethnic discrimination leaves a strong mark on migrants' psychological state, even when controlling other well-known factors that lead to psychological difficulties. Research conducted in Germany on a sample of citizens of Turkish origin (who make up a significant minority in German society) indicates that there is ethnic discrimination and affected psychological difficulties like anxiety and depression, even when they are controlled factors such as marital status, employment, status in the state and personal factors. The disproportion between the acculturation process dominant in the dominant culture and personal preferences of the individual basis is ethnic discrimination in Germany. It leaves traces on Turkish immigrants, indicating the devastating impact of discriminatory behavior migrants even in the case of a relatively orderly and stable community of Turks in Germany, in which new and old Turkish migrants live (Aichberger et al., 2015).

Given the importance of situational and environmental factors on the occurrence of depressive and anxiety spectrum disorders, it is clear that refugees face much more complicated risk factors than general populations, such as institutionalized prejudices, especially in the field of mental health care, disproportionate social 
exclusion and economic hardship, and discrimination. Refugees often must accept jobs that do not suit their education level, and in this domain, they experience psychological distress that can lead to mental difficulties (Close et al., 2016). To similar results, Giacco and associates are coming in their review work, finding that for higher risk of PTSD in migrants than domicile populations exists for several reasons. Some of them are variously traumatic events before the migration process, in the country from which they come, like abuse, scenes of violence, war events, and the like, and the process itself transit to the country of asylum and stay until asylum is granted.

We can problematize that society is possible only when people consider a large number of cases from the same aspect; when they have the same opinion about a large number of cases when the same facts give rise to the same impressions and thoughts." (Tocqueville, 1999, p. 368) In every democratic community, one must find the embodiment of the media of state integration and supranational solidarity necessary to form a collective political will for the legitimacy of power. Thus, the state must exist with a human and social fabric consistent with it, as a political entity, within the established solidarity factors. Moreover, "transnational civic solidarity expansion depends on learning processes, and the current migrant crisis can stimulate the perception of the state of needs in which the economy and politics of countries find themselves." (Habermas, 2013, p. 76) It is also undisputed that the degree of tolerance of diversity cannot be unlimited, especially if there is a risk of undermining Western culture's fundamental characteristics, starting with democracy and liberal freedoms.

\section{THE MASS MEDIA}

The media presentation of the refugee crisis and human tragedy emphasizes the humanitarian dimension of the events, ignoring the causes and relativizing the security issue. It represents a communication model or media strategy that obscures the model of presenting events (event causes and security issues), consciously mixing cause and effect in programmed manipulation of "confusing" the public. We have the following strategies: distraction (inversion of the issue), producing problems, then offering solutions, gradual strategy in terms of continuous production of free consent, then delay strategy or announcement of unpopular changes, the infantilization of the public - delusion, then emotional strategies (manipulation of fears and emotions), ignorance and mediocrity in which the less educated are the vulnerable target of manipulation and production of consent. In this self-blam, the individual feels that he is guilty of their position and strategy of "getting to know individuals better than themselves to establish control and power over human behavior. 
When we talk about the media's action as a mirror of society, we would conclude that the media literally shows us what is happening, without adding information and embellishment, but is it always so? We could problematize that the phrase "media as a mirror of society" can be justified, but not in the sense of its literal interpretation. Thus, media that would transmit or mirror some objective reality, the factual truth about society. This phrase can serve as a guide to a more sophisticated understanding of media forms, organizational and editorial policies of media institutions, program contents, and production-consumption matrices produced through them and understanding the society itself within which economic, political and cultural preconditions for media functioning arise. (Hromadžić, 2014, p. 20) The vital question arises: what exactly do the media publish about Islam, and what impact does it have on the public? To answer that question, we need to pay attention to the wide selection of news in the media. If we connect this with publishing about Islam, we can conclude that we will hear only negative things about Islam in the American and European media, because even the little positive/good news that is published, it is expected that it will be published from the "domestic" area.

There is no policy that is not dependent on the media. Mass media, if prone to populist actors, can facilitate their action and strengthening. Contemporary trends in policy reporting amplify populist speech and create a basis for the rise of populist options (Grbeša \& Šalaj, 2018, p. 140). Due to the "intrusion" of the media, media coverage contributes to the creation of a sense of irrational fear of newcomers and harm to refugees, which is criminalized and labeled as a social, cultural, economic, social, security, territorial, health, demographic and other threat. For example, after New Year's Eve in Cologne in 2015, when immigrants allegedly sexually harassed and raped hundreds of girls and women, the event's news became groundbreaking. A subsequent police investigation determined that only three of the 58 suspected perpetrators were immigrants. (De Correspondent, 2016) The results of the investigation arrived too late. Within the migrant wave, all immigrants were considered Muslims, and after the terrorist attack in Paris and Cologne, they have been equated with rapists. It is deliberately creating a parallel reality and even a particular language. So they placed the word refuges, which is a combination of two words - rape and refugee. By addressing likeminded people through profiled media, they created an explosive and antagonistic atmosphere.

One of the possible approaches in analyzing the media's role is dehumanizing migrants as a theoretical framework. "Dehumanization involves denying other people's full humanity and their exclusion from species." (Esses et. al., 2013) In this article's context, the presentation must play the connection between the process of dehumanization and the media role, the most crucial role immigrants as health threats. However, there was little direct evidence for this claim. As a 
goal in their research, they set out to determine the possible causal relationship between the negatives media descriptions of immigrants and refugees and the dehumanization of these groups. By observing earlier literature, one could conclude that immigrants' and refugees' negative media coverage is likely to lead to certain groups' dehumanization. Experiments investigated the potential consequences of threat-focused media coverage that immigrants and refugees represent to the receiving countries' members. The threats they made dealt with those that, in their opinion, predominate in the media immigrants are the source and transmitters of various diseases; asylum seekers are, in fact, false asylum seekers and attempt this fraud take advantage of the system and refugee status to enter Western countries; terrorists are trying to enter western countries as asylum seekers. (Esses et. al., 2013)

This study confirmed that exposure to depictions of immigrants as vectors of disease is associated with a more robust perception of immigrants as health threats, which has resulted in the dehumanization of immigrants in participants in the experiment. Furthermore, for the second type of threat, the experiment of content exposure (which portray immigrants as false refugees) significantly increased the degree of dehumanization of immigrants as a group. Furthermore, the third assumption was confirmed and established that participants in the third experiment also intensively dehumanized immigrants after exposure information on refugees and asylum seekers as a group to which to some belonged to terrorist organizations.

The media construction of "hate behind the curtain" on the Balkan route, often unverified information, civic passivity, the indifference of the state, and inefficient system towards the problem of migrants and control mechanisms, as a person without identity, create a "feeling of intolerance." (EU Council, 2015) The media practically create opinions and attitudes on certain topics by emphasizing specific values, facts, or other aspects to which they attach greater relevance than would be done in a different context. In other words, they shape opinions by merely highlighting the problem's specific features as more critical than others, which is why they ultimately carry more weight in the final position (Nelson, 1997).

The media in Bosnia and Herzegovina (B\&H) was mostly pessimistic and written in "fighting" against migrants and the migrant crisis. Some of the news had a milder and more humane connotation, such as stories about severe living conditions from which migrants fled and the hope they have for a better life in the countries they went to (Sokolović, 2019), and some expressed concern about severe conditions in by which migrants stay in reception centers and the state and the E.U. do not care for this population. The excessive use of the name "migrant" is also problematic. It depersonalizes a person further, diminishes human 
qualities, and views those who came from different parts of the world as some homogeneous mass without a name, surname, and past. "Migrants fought," Migrants robbed," "Fight of migrants," and similar media headlines as if they want to be further deprived of human qualities and dignity. Individual media constantly repeat the word migrant, which is mostly mentioned in a highly negative or victimization context. As reminders, in 2018 year sheet, Dnevni Avaz took the lead in negative announcements on account of migrants, accusing them of uncivilized behavior, use of narcotics, traumatizing the local population, constant fights, and robberies citizens.

On the other hand, many media avoid use refugee terms, thus disregarding the possibility of persons leaving their own homes for fear of endangering human rights or fear for life and security. Let us also remember two articles published in 2018 in the notable Bosnian newspaper Dnevni Avaz. In one, the Prosecutor of the Prosecutor's Office of B\&H G.B. told the independent newspaper that a migrant robbed her in a shop in the center of Sarajevo. Although she could not confirm that it was a migrant because the police missed her the perpetrator, the plaintiff corroborated such a claim with a description of the robbers, stating that she is dark-skinned. Other media quickly spread the news in B\&H. Another text was published in Dnevni Avaz in July 2018 citizens are informed that migrants from Afghanistan have "the latest hobby "- hunting and grilling wild ducks. The source for such a claim is two citizens who wished to remain anonymous.

The antagonistic stereotypical narrative about migrants starts from the thesis that they constitute a retrograde social group representing an economic and security threat to the domicile population. It is not capable of cultural assimilation in the countries of transit, reception, and final destination. One of the biggest problems in intercultural relations is the experience of intergroup threat. Although the experience of threat may arise from conflicts over limited resources, this experience does not have to be firmly grounded in objective reality or arise from real conflict within the theory of threat. A realistic threat encompasses a threat to the group's economic or political power and its physical well-being, while a symbolic one poses a threat to the group's identity. On the other hand, intergroup anxiety and stereotypes create a sense of threat because they imply negative expectations about the interaction (anxiety) and the behavior of members of the outside group (stereotypes). Stereotypes arise when people are not sufficiently informed about certain groups of people or specific cultures.tabstaStereotypes develop in almost all situations, and one such example is a series of stereotypes that degenerated towards Jews during World War II and Hitler's rule in Germany. Stereotypes always exist, and they arise due to the non-acceptance of specific individuals or groups due to different actions and functioning. According to ethnicity and religion, classification should not exist in any situation, let alone in crises. It is wrong to list any ethnic or religious epithet such as Arab, Muslim, or 
The Migrations and the Mass Media; Conceptualization of the Freedom from Fear and Want Paradigm

Syrian next to the refugee's name. These types of threats lead to prejudice and discriminatory behavior towards members of the outside group, and according to Integrated treat theory, an intergroup threat is experienced when members of one group perceive that another group is in a position to cause them some form of harm. (Stephan \& Stephan, 2020) Thus, constructing immigrants as a group tends to encourage the perception that "their "interests, values, and traditions are competing with "ours." (Hadžić, 2020)

\section{FREEDOM FROM FEAR AND WANT PARADIGM}

The Universal Declaration represents the sum of various rights that have historically received their testimonies in the struggle for greater freedoms and a wider equality field. It also contains excellent hopes of that time: that the rule of law is achievable, that no one (anymore) should be subjected to torture, that national and international frameworks are permeable, that people have the right to migration, to a nationality. It is also a list of freedoms that human beings should enjoy in conditions that were believed to occur after 1945, in conditions of lasting peace necessarily.

The most significant causes of large population migrations are, for the most part, security, social and economic-propaganda nature. These causes are mostly induced through crises, wars, and military interventions of leading countries Of the West, guided exclusively by neoliberal capitalism's values and logic. The ultimate value in that system is money (capital), not man. The chaos caused in many world regions has moved millions of poor, displaced, disenfranchised, and vulnerable to leave their home countries searching for a new life. The principle of non-refoulment is a fundamental principle defined by the Convention Relating to Refugees 1951. Protects refugees outside the country of origin from being forcibly returned to an area is the likelihood of being persecuted, tortured, or killed. Article 33 of the Convention reads: "No Contracting State may expel or return a refugee, to an area where his or her life or liberty would be endangered by care- not racial, religious, or national affiliation or because of belonging to a particular social group or a political one opinions." While it is rightly held that poverty is one of the leading causes of human rights threats and that development can break the vicious circle of poverty, in many African, Latin American, and Asian countries, development is seen as a source of violence against human rights. In many development policies of the countries there, development is equated with the following negative phenomena: depletion of non-renewable natural resources; appropriation of the goods of poor peoples; excessive use of chemicals in agriculture leading to soil and water pollution and in some cases disruption of food chains; accelerated industrialization of imported technologies and waste; development of tourism based on the construction of large hotel 
complexes that deprive the local population of space and resources, mostly water; prostitution, including children; population displacement, especially of indigenous tribes; mega-development projects that bring countries into debt; increasing injustice and corruption.

There are currently numerous armed conflicts in the world that sample victims and destroy infrastructure and economic losses. Economic inequality is truly globalized and can be seen in every aspect of society, in all sectors and categories. Economic inequality has also increased significantly in all rich countries since 1975, except Germany. Nearly 690 million people worldwide are malnourished. One hundred forty-four million children have slowed growth due to malnutrition. Forty-seven million children are starving, and 5.3 million children died before their fifth birthday, often due to malnutrition. The poverty rate or social exclusion fell again on the level at which it was formerly financial crisis 2008approximately 118 million people, or $23.5 \%$ of the European Union population. In 2016, the proportion of people at risk of poverty or social exclusion in the EU amounted to 25\%. (EU Commission, 2017) COVID-19 pandemic with all economic consequences could double the number of people at risk of acute food production and supply crises.

All the above examples indicate that there is a discrimination climate against migrants and refugees. The Trump politics or the French legislative solution restricting the right to express one's religious affiliation in public is another argument. It is hard to believe in the credibility of the argument that dressing members of one religious community violate the rights of other members of society, and the argument about preventing possible terrorism speaks of two things: on the one hand, that society's right to freedom from fear is institutionally questioned. Prejudices and stereotypes about a community are given priority over the concept of social integration. It extends the principle of restricting freedom from France to the entire European political space as legitimate, which will, in the long run, hinder the political integration of the minority religious community into society while pushing freedom of religion, freedom of expression, and even building societies free from fear. By no means do these actions not contribute to society's development.

Democracy is a broad concept. Chomsky speaks of two conceptions of democracy. One conception of democracy considers it democratic society is one in which the public has the means to participate in some meaningful way in the resolution in their jobs, and media are open. The second conception of democracy is that the public must be prevented from managing its affairs, and the media must be kept under strict and close control. (Chomsky, 2014) What is hiding behind the word democracy is difficult to decipher and, it seems that today everyone tailors democracy as he thinks is right. Democracy concept solely should be 
The Migrations and the Mass Media; Conceptualization of the Freedom from Fear and Want Paradigm

realized fundamental freedoms and human rights. However, is it like that? The call for discrimination is just one segment that shows that man is not yet civilized enough and not ready to accept humanism principles.

The author maintains that national security is an issue facing all people, and national security is the security of a nation that, along with society and the state's security and the state, is a universal good. Grizold (1998) states that national security is an integral part of international security, which consists of generally accepted values by which international entities regulate their mutual relations. In his address to Congress on January 6, 1941, US President Roosevelt listed four fundamental human freedoms: freedom of speech and expression, freedom of religion, freedom from scarcity, and freedom from fear of arms. This Roosevelt speech served as a fundamental principle of defining human security in the 1994 UNDP report. In this report, it is possible to single out seven related human security elements: economic security, food security, health security, environmental security, personal security, social security, and political security. (UNDP, 1994) What keeps the Universal Declaration in the form of a promise? In addition to the fact that it has never become a legally binding document, it could be said that its spirit, rather than its word, is what is left as a pledge to the world that is yet to come. Its implicit assumption, caused by the specific circumstances in which it arises, is that world peace is necessary so that everyone in the human community can have the right to life. To have the right to life, live it, is a condition of the possibility of any other right, and then of any duty towards the communities we elect and to which we belong.

The Universal Declaration is often presented as the last in a series of great charters of liberties. Its language and framework lean on the aspirations that first took shape in the Magna Carta and were further articulated by the 17th and 18th centuries' famous declarations. The preamble confirms this: in it, we find various strongholds of previous attempts to reach binding formulations of freedom and equality - equal and inalienable rights of all members of the human family which are taken as the foundation of freedom, justice, and peace in the world; the right to rebel against tyranny and oppression and the demand that human rights be protected by the rule of law; belief in the inherent dignity and value of the human person and the equal rights of men and women. (Singh, 2015) The context in which the Universal Declaration was drafted causes the preamble to emphasize the necessity of friendly relations between nations and freedom from fear and scarcity, which should belong to every human being.

However, we should raise the question of the importance of human security and determine whether it is functional. Namely, today, most of the world's armed conflicts are fought in sub-Saharan Africa, challenging to control or end. Rising poverty, declining GDP, and minimal aid do not provide much peace, especially 
given the abundance of cheap weapons and experiences from previous wars. Besides, the rise in wars exacerbates the conditions that led to the conflict's onset, creating a classic "conflict trap" that poses a significant challenge to maintaining peace treaties (Kerr, 2010, p. 116). We need to seeks to present current issues related to the definition of human security. "If human security applies to everything, it does not apply to anything." (Starcevic, 2015) The already mentioned controversies regarding the definition of human security have led to the following dilemma: should migration be considered a security issue, or is it a natural phenomenon? Namely, the whole concept is insufficiently defined, precise, and incorrect, so it encompasses almost everything and does not imply anything. When we talk about liberation from need, we want to look for ways to keep and deny access to basic needs. Moreover, relieving fear means that no one should be afraid of their government, armed forces, unduly acting police, or even their neighbors.

\section{CONCLUSION}

It is important to emphasize that migration is an essential factor of human and international security, and the lack of adequate normative dynamics neglects human rights and accelerate new conflicts. Social identity and the internalization of group values and the external group's perception as a threat, and in the political aspect, the acceptance of more conservative political ideologies that propagate the protection of these same group values, are the primary sociopsychological mechanisms of prejudice. The dominant tone in the media indicates a suspicious attitude towards migrants' rationality. The term migrant, and such homogenization in which a group of people tries to portray themselves as a mass in which all have the same characteristics, goals are fertile ground for expanding hate speech, incitement, and various forms of generalization.

Refugees and migrants are not recognized as relevant and valuable sections of the assembly with particular interests and needs (e.g., concerning information on rights, resources, and duties, and the opportunity to develop a voice that can be heard). Everyone is a political subject because the right to life is a political right, regardless of socioeconomic status within the right to a good life concept, which implies a list of possibilities and privileges that are named and recognized by the Universal Declaration. Viewing members of other cultures as "enemies" or "others" that can harm collective identity is not a liberal principle but a nationalist one, and a significant portion of anti-migrant attitudes are interpreted from a cultural perspective. In addition to the threat of terrorism, which is regularly associated with Islam, general decline in citizens' feelings of security, and antiimmigration attitudes and prejudices are often reflected through contextually and 
group- specific stereotypes. We have a rise of stereotypes that represent a generalization based on limited experience.

Ethnic discrimination and economic inequality jeopardize the human security paradigm impacting psychological well-being within moderators' influence and in mind attending actual conflicts. This type of stress further undermines the individual's psychological stability. The fight against hate speech must be reactive (sanctioning hate speech in public space and removal malicious content from the media and social networks) and proactive media education and media literacy programs aimed at the general population. The freedom of expression does not include the right to hate speech. In parallel with the prevention of hate speech, raising quality standards, and social responsibility, media should be imperative. Minimizing sensationalism journalism undermines the quality of public debate and thus, in a way, legitimizes its low level of communication culture in the public space from which it develops and inappropriate speech, even hate speech, flourishes uncontrollably.

Prevention programs of media propaganda as a separate phenomenon based on proper longitudinal, multidisciplinary research into the etiology and consequences can contribute to human rights and human security. By accepting liberal principles, states should promote equality and respect for society's identity. Public policies should promote not only economic but also cultural and intangible equality. The initiative to begin affirmative actions and migrants' participation in socio-economic and political systems means realizing the preconditions for cultural integration, which is critical.

\section{REFERENCES}

Chomsky, N. (2002). Media Control, The spectacular achievements of propaganda. New York: Seven Stories Press.

Citrinm, J., Sears, D., Muste, C. \& Wong, C. (2001). Multiculturalism in American public opinion. British Journal of Political Science, 31(2) 247275, https://doi.org/10.1017/S0007123401000102

The European Union Council, (2015). Report.

https://www.consilium.europa.eu/en/press/pressreleases/2015/11/09/jha-council-conclusions-on-measures-to-handlerefugee-and-migration-crisis/

Grbeša, M., Šalaj, B. (2018). Good, bad, or evil? Populism in Croatia, Zagreb: TIM Press 
Habermas, J. (2012). Europe and democracy: an exchange, The Crisis of the European Union in the Light of a Constitutionalization of International Law, The European Journal of International Law, 23(2), 335-348.

Sokolović, H. (2019). Bolje od života od kojeg su pobjegli, gore od onog kojem teže. http://ba.nlinfo.com/Vijesti/a380566/N1-u-hotelu-Sedra.html

Giacco, D., Laxhman, N. \& Priebe, S. (2018). Prevalence of and risk factors for mental disorders in refugees. Seminars in Cell \& Developmental Biology, 77, 144-152, https://doi.org/10.1016/j.semcdb.2017.11.030

Close, C., Kouvonen, A., Bosqui, T., Patel, K., O’Reilly, D. \& Donnelly, M. (2016). The mental health and wellbeing of first generation migrants: a systematic-narrative review of reviews. Globalization and Health, 12(1), 47, 10.1186/s12992-016-0187-3

Aichberger, M., Bromand, Z., Rapp, M., Yesil, R., Montesinos, A., TemurErman, S. \& Schouler-Ocak, M. (2015). Perceived ethnic discrimination, acculturation, and psychological distress in women of Turkish origin in Germany. Social Psychiatry and Psychiatric Epidemiology, 50(11), $1691-1700$

Al Jazeera (2018). Rasizam u Poljskoj sve snažniji [Racism more stronger in Poland]. http://balkans.aljazeera.net/vijesti/rasizam-u-poljskoj-svesnazniji

Beirich, H. \& Buchanan, S. (2018). The Year in Hate and Extremism. https://www.splcenter.org/fighting-hate/intelligence-report/2018/2017year-hate-and-extremism

Esses, M., Medianu, S. \& Lawson, A. (2013). Uncertainty, threat, and the role of the media in promoting the dehumanization of immigrants and refugees. Journal of Social Issues, 69(3), https://doi.org/10.1111/josi.12027

Grizold, A. (1998). Medunarodna sigurnost i etnički konflikti. Politička misao, 35(4), 22-35. http://hrcak.srce.hr/32206

Hadžić, F. (2020). The European Union (EU) Political Identity within the migrant crisis, and the Balkan - Bosnian route; xenophobia and religious identity. Research, Society and Development, 9(10), 1-30, e4809108685. https://doi.org/10.33448/rsd-v9i10.8685

Starcevic, I. (2012). Mirovne operacije u postmoderno doba /Peace operations in the postmodern age. Doktorski rad. Fakultet političkih znanosti Sveučilišta u Zagrebu. 
The Migrations and the Mass Media; Conceptualization of the Freedom from Fear and Want Paradigm

Kerr, P. (2010). Human security, Contemporary Security Studies, ed. A. Collins, Zagreb: Politička kultura.

Tajfel, H. \& Turner, J. C. (2004). The Social Identity Theory of Intergroup Behavior. In J. T. Jost \& J. Sidanius (Eds.), Key readings in social psychology. Political psychology: Key readings, Psychology Press, 276293, https://doi.org/10.4324/9780203505984-16

European Commission, (2017), Tematski informativni članak o europskom semestru, Socijalna isključenost.

https://ec.europa.eu/info/sites/info/files/file_import/europeansemester_thematic-factsheet_addressing-inequalities_hr.pdf

Stephan, W. \& Stephan, C. (2000). An integrated threat theory of prejudice. In S. Oskamp (Ed.). The Claremont Symposium on Applied Social Psychology, Reducing prejudice and discrimination, Lawrence Erlbaum Associates Publishers, 23-45.

Chomsky, N. (2014) Democracy and Power. The Delhi Lectures. Democracy and Power. The Delhi Lectures. Introduction by Jean Drèze. Cambridge: Open Book Publishers. https://doi.org/10.11647/OBP.0050

UNDP, (1994). Human Development Report New Dimensions of Human Security. $\quad \mathrm{http} / / \mathrm{hdr}$.undp.org/en/content/human-development-report1994

Singh, R. (2015). The development of human rights thought from Magna Carta to the Universal Declaration of Human Rights, from IV - The contemporary inheritance of Magna Carta, Cambridge: Cambridge University Press. https://doi.org/10.1017/CBO9781316178164.016

Taylor, O. (2004). Human Security - Conflict, Critique and Consensus: Colloquium Remarks and a Proposal for a Threshold-Based Definition. Security Dialogue, 35(3), 373-387.

Nelson, T. (1997). Media Framing of a Civil Liberties Conflict and Its Effect on Tolerance. American Political Science Association, 91(3), 567-583. $10.2307 / 2952075$

De Correspondent, (2016). Time for the facts. What do we know about Cologne four months later? https://thecorrespondent.com/4401/time-for-thefacts-what-do-we-know-about-cologne-four-monthslater/1073698080444-e20ada1b 